\title{
PENGEMBANGAN MEDIA PEMBELAJARAN E-MATERI DENGAN MODEL PEMBELAJARAN BEBASIS MASALAH PADA MATERI SUHU DAN KALOR
}

\author{
Ramlan $^{1}$, Haeruddin ${ }^{2}$ dan Kamaluddin ${ }^{3}$ \\ Email : ramlan_physics09@yahoo.com \\ Program Studi Pendidikan Fisika, Jurusan Pendidikan MIPA, Universitas Tadulako \\ Jl. Soekarno Hatta Km. 9 Kampus Bumi Tadulako Tondo Palu - Sulawesi Tengah
}

\begin{abstract}
Abstrak - Pengembagan media pembelajaran ini bertujuan untuk menghasilkan suatu media yang dapat membantu mengatasi permasalahan dalam proses pembelajaran karena keterbatasan waktu dan alat peraga. Penelitian ini melalui 4 tahap uji coba yaitu uji coba ahli materi, uji coba ahli media, uji coba kelompok kecil dan uji coba kelompok basar yang dilaksanakan di SMAN 5 Palu, SMAN 3 Palu dan SMAN 2 Palu. Model pengembangan yang digunakan yaitu model pengembangan Dick, Carey \& Carley. Pengumpulan data dilakukan dengan metode angket dan wawancara. Hasil analisis angket yang diperoleh dari tahap uji coba yaitu: uji coba ahli materi 78,89\% (Baik), uji coba ahli media 80,91\% (Baik), uji coba kelompok kecil 85,34\% (Sangat Baik) dan uji coba kelompok besar yang dilakukan di 3 Sekolah menunjukkan bahwa media pembelajaran e-materi dengan model pembelajaran berbasis masalah pada materi suhu dan kalor ini sesuai dengan kebutuhan sekolah dan dapat digunakan di sekolah-sekolah dengan fasilitas mendukung.
\end{abstract}

Kata Kunci: Pengembangan; Media pembelajaran; e-materi; model pembelajaran berbasis masalah; Suhu dan Kalor

\section{PENDAHULUAN}

Pendidikan merupakan salah satu keperluan pokok manusia dalam berpikir. Tanpa pendidikan manusia tidak akan memiliki pengetahuan dan keahlian dalam melakukan pekerjaan atau sesuatu dalam kehidupan. Berbagai usaha telah dilakukan untuk meningkatkan mutu pendidikan, salah satunya yaitu dengan memanfaatkan teknologi informasi dan komunikasi (TIK) dalam proses belajar mengajar. Kemajuan teknologi informasi dan komunikasi (TIK) saat ini telah membawa berbagai perubahan dalam kehidupan manusia. Kemajuan tersebut semakin dirasakan di berbagai sektor, utamanya di bidang pendidikan.

$$
\text { Pada umumnya dalam kegiatan }
$$
pembelajaran tenaga pendidik hanya menggunakan bahan ajar cetak, salah satunya buku pelajaran atau buku teks. Buku pelajaran dalam dunia pendidikan merupakan suatu kebutuhan pokok bagi guru maupun siswa sebagai pedoman dalam kegiatan pembelajaran sehingga dapat mencapai kompetensi yang diharapkan. Namun, kegiatan pembelajaran yang menggunakan bahan ajar cetak memiliki kelemahan yaitu pemaparan materi bersifat linear, kegiatan pembelajaran terpusat pada guru, materi ajar disajikan dalam bahasa yang sulit dimengerti oleh siswa dan bentuk informasi disajikan secara terbatas yaitu dalam bentuk teks dan gambar. Setiap materi pembelajaran mempunyai tingkat kesukaran yang bervariasi. Pada satu sisi ada materi pembelajaran yang tidak memerlukan media pembelajaran, tetapi di sisi lain ada materi pembelajaran yang memerlukan media pembelajaran. Materi pembelajaran yang mempunyai tingkat kesukaran tinggi tentu sukar dipahami oleh siswa, apalagi oleh siswa yang kurang menyukai materi pembelajaran yang disampaikan. Oleh karena itu, diperlukan media sebagai alat bantu dalam proses pembelajaran sehingga materi pembelajaran dapat disampaikan secara efektif dan efisien.

Pemanfaatan teknologi komputer juga sudah pernah diteliti oleh beberapa peneliti. menurut [1], menyatakan bahwa "pembelajaran dengan menggunakan aplikasi komputer memberikan kesempatan kepada peserta didik untuk belajar secara dinamis dan interaktif". Selain itu, ia juga menyatakan bahwa "Penggunaan aplikasi komputer sebagai media 
ISSN 23383240

interaktif dapat menciptakan iklim belajar yang efektif bagi siswa yang lambat (slow learner), dan dapat memacu efektifitas belajar bagi siswa yang lebih cepat (fast learner)". Menurut [2], menyimpulkan bahwa "penggunaan media pembelajaran berbasis teknologi informasi dapat memperlancar proses pembelajaran dan mengoptimalkan hasil belajar".

\section{METODOLOGI}

Penelitian ini menggunakan metode penelitian pengembangan. Penelitian Pengembangan adalah rangkaian proses atau langkah-langkah dalam rangka mengembangkan suatu produk baru atau menyempurnakan produk yang telah ada. Produk yang dimaksud adalah media pembelajaran e-materi dengan model pembelajaran berbasis masalah pada materi suhu dan kalor. Pengembangan media pembelajaran e-materi dengan model pembelajaran berbasis masalah pada materi suhu dan kalor ini menggunakan model pengembangan yang mengacu pada model Dick, Carey \& Carley yang telah dikembangkan [3].

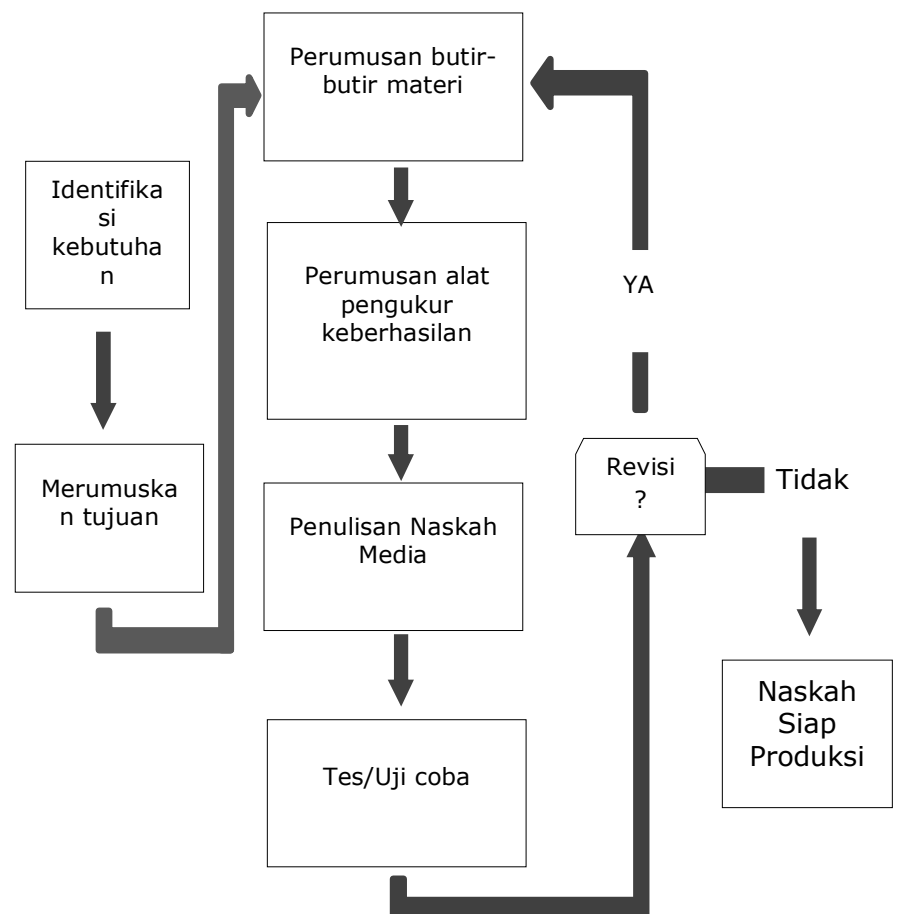

Gambar I Bagan alir pengembangan Media Pembelajaran

Instrumen yang digunakan dalam
penelitian pengembangan ini adalah angket

tanggapan/penilaian ahli dan angket respon siswa. Data yang terkumpul adalah data hasil penilaian/tanggapan ahli materi, ahli desain media, uji coba kelompok kecil, dan uji coba kelompok besar. Seluruh data yang diperoleh untuk mempermudah analisis dikelompokkan ke dalam jenis data kualitatif. Hasil data kualitatif dikualifikasikan dengan menggunakan skala Lickert (skala lima) untuk proses analisa data.

Analisis data tiap komponen baik hasil penilaian ahli, kelompok kecil dan uji coba lapangan dilakukan analisis deskriptif berupa rerata dan persentase. Pemberian makna dan pengambilan keputusan menggunakan kriteria sebagai berikut:

TABEL 1 PEMBERIAN MAKNA DAN PENGAMBILAN KEPUTUSAN

\begin{tabular}{|c|c|c|}
\hline $\begin{array}{c}\text { TABEL } 1 \text { PEMBERIAN MAKNA DAN PENGAMBILAN KEPUTUSAN } \\
\text { Pencapaian }\end{array}$ & Kualifikasi & Keterangan \\
\hline $85 \%-100 \%$ & Sangat Baik & Tidak Perlu Direvisi \\
\hline $75 \%-84 \%$ & Baik & Tidak Perlu Direvisi \\
\hline $65 \%-74 \%$ & Cukup Baik & Perlu Direvisi \\
\hline $55 \%-64 \%$ & Kurang Baik & Perlu Direvisi \\
\hline $0 \%-54 \%$ & $\begin{array}{c}\text { Sangat Kurang } \\
\text { Baik }\end{array}$ & Perlu Direvisi \\
\hline
\end{tabular}

III. HASIL DAN PEMBAHASAN

Hasil pengembangan media pembelajaran e-materi dengan model pembelajaran berbasis masalah pada materi suhu dan kalor diperoleh dari tahap persiapan hingga serangkaian uji coba baik uji coba ahli isi materi, uji coba ahli media, uji coba kelompok kecil dan uji kelompok besar. Berikut adalah pemaparan dari hasil pengembangan media pembelajaran e-materi dengan model pembelajaran berbasis masalah pada materi suhu dan kalor.

\section{1) Tahap Persiapan}

Tahap ini meliputi kegiatan identifikasi Kebutuhan, perumusan tujuan, perumusan butirbutir materi, penyusunan naskah media dan perumusan alat pengukur.

\section{2) Uji Coba Ahli Materi}

Data hasil analisis angket penilaian dari ahli materi suhu dan kalor dapat dilihat pada tabel berikut: 
ISSN 23383240

TABEL II HASIL ANALISIS ANGKET PENILAIAN DARI AHLI MATERI SUHU DAN KALOR

\begin{tabular}{|c|c|c|c|c|c|}
\hline \multirow{3}{*}{ No } & \multirow{3}{*}{ Pokok Bahasan } & \multirow{2}{*}{\multicolumn{2}{|c|}{$\begin{array}{l}\text { Hasil (\%) } \\
\text { Validator }\end{array}$}} & \multirow{3}{*}{$\begin{array}{l}\text { Rata- } \\
\text { Rata } \\
\text { Hasil } \\
(\%)\end{array}$} & \multirow{3}{*}{ Kualifikasi } \\
\hline & & & & & \\
\hline & & V1 & V2 & & \\
\hline \multirow[t]{2}{*}{1} & Pendahuluan & 80 & 80 & 80 & Baik \\
\hline & \multicolumn{5}{|c|}{$\begin{array}{l}\text { Komentar/Saran } \\
\text { Penguraian masalah sebaiknya satu kasus satu alinea } \\
\text { sehingga nampak perbedaannya }\end{array}$} \\
\hline \multirow[t]{4}{*}{2} & \multicolumn{5}{|l|}{$\begin{array}{l}\text { Suhu dan } \\
\text { Pemuaian }\end{array}$} \\
\hline & A. Suhu & 75 & $\begin{array}{c}82, \\
5\end{array}$ & 78,75 & Baik \\
\hline & B. Pemuaian & $\begin{array}{c}75,6 \\
5 \\
\end{array}$ & 80 & 77,83 & Baik \\
\hline & \multicolumn{5}{|c|}{$\begin{array}{l}\text { Komentar/Saran } \\
\text { 1. Gambar ( } 6.4 \text { ) kurang relevan } \\
\text { 2. Penjelasan pada contoh soal (6.3) tidak sesuai } \\
\text { dengan pertanyaan }\end{array}$} \\
\hline \multirow[t]{2}{*}{3} & $\begin{array}{l}\text { Kalor dan } \\
\text { Perubahan Wujud }\end{array}$ & $\begin{array}{c}76,6 \\
7 \\
\end{array}$ & 80 & 78,34 & Baik \\
\hline & \multicolumn{5}{|c|}{$\begin{array}{l}\text { Komentar/Saran } \\
\text { Apersepsi pada sub pokok bahasan pengaruh kalor } \\
\text { terhadap zat sebaiknya diambil dari fenomena sehari- } \\
\text { hari }\end{array}$} \\
\hline \multirow[t]{2}{*}{4} & Perpindahan Kalor & $\begin{array}{c}83,3 \\
3 \\
\end{array}$ & 80 & 81,67 & Baik \\
\hline & \multicolumn{5}{|c|}{$\begin{array}{l}\text { Komentar/Saran } \\
\text { Tidak ada komentar }\end{array}$} \\
\hline & Rata-Rata & $\begin{array}{c}78,1 \\
3 \\
\end{array}$ & $\begin{array}{c}80, \\
5\end{array}$ & 79,32 & Baik \\
\hline
\end{tabular}

Tingkat pencapaian yang diperoleh dari hasil penilaian angket uji coba ahli materi yaitu sebesar 78,89 \% nilai tersebut menunjukkan bahwa materi termasuk dalam kriteria baik. Data yang diperoleh dari hasil uji coba ahli materi yaitu data kualitatif dalam bentuk komentar dan saran terhadap materi pembelajaran. Hasil komentar dan saran yang diperoleh dari ahli materi I dan ahli materi II tersebut yang kemudian digunakan oleh peneliti untuk merevisi materi yang akan dimuat dalam media yang dikembangkan.

\section{3) Uji Coba Ahli Media}

Data hasil analisis angket penilaian dari ahli desain media dapat dilihat pada tabel berikut:
TABEL III HASIL ANALISIS ANGKET PENILAIAN DARI AHLI MEDIA

\begin{tabular}{|c|c|c|c|c|c|}
\hline \multirow{3}{*}{ No } & \multirow{3}{*}{ Item } & \multirow{2}{*}{\multicolumn{2}{|c|}{$\frac{\text { Hasil (\%) }}{\text { Validator }}$}} & \multirow{3}{*}{$\begin{array}{c}\text { Rata-Rata } \\
\text { Hasil (\%) }\end{array}$} & \multirow{3}{*}{$\begin{array}{c}\text { Kualifik } \\
\text { asi }\end{array}$} \\
\hline & & & & & \\
\hline & & V1 & V2 & & \\
\hline \multirow[t]{2}{*}{1} & Template exe & 70 & 90 & 80 & Baik \\
\hline & \multicolumn{5}{|c|}{$\begin{array}{l}\text { 1. Akan lebih baik penempatan Menu Navcontainer } \\
\text { diset di tengah setelah header agar tidak terkesan } \\
\text { kosong dan menarik. } \\
\text { 2. Minim Animasi. }\end{array}$} \\
\hline \multirow[t]{2}{*}{2} & $\begin{array}{c}\text { Home (Front } \\
\text { Page) }\end{array}$ & 68 & 94 & 81 & Baik \\
\hline & \multicolumn{5}{|c|}{$\begin{array}{l}\text { 1. Pada Header, gambar background tidak perlu } \\
\text { menggunakan repeat- } x \text {. } \\
\text { 2. Posisi header sebaiknya ditempatkan di tengah } \\
\text { sehingga terlihat rapih dan menarik }\end{array}$} \\
\hline \multirow[t]{2}{*}{3} & $\begin{array}{c}\text { Materi } \\
\text { Pembelajaran }\end{array}$ & 70 & 100 & 85 & Baik \\
\hline & \multicolumn{5}{|c|}{$\begin{array}{l}\text { Komentar/Saran } \\
\text { Secara umum tidak ada }\end{array}$} \\
\hline 4 & $\begin{array}{c}\text { Uji } \\
\text { Kompetensi } \\
\text { Diri }\end{array}$ & 65 & 85 & 75,00 & Baik \\
\hline
\end{tabular}

\section{Komentar/Saran}

1. Content Uji Kompetensi Diri soal terkesan kaku \& minimnya penggunaan animasi

2. Logo (petunjuk/kunci jawaban) yang digunakan haruslah jelas. Pastikan users mengetahui logo tersebut adalah kunci jawaban, bukan petunjuk soal

3. Jawaban yang telah dipilih sebaiknya tidak bisa diganti (button/jawaban yang lain dinon aktifkan)

Rata-Rata

\begin{tabular}{l|l|l}
68,25 & 92,25 & 80,25
\end{tabular}

Baik

Tingkat pencapaian yang diperoleh dari hasil penilaian angket uji coba ahli media yaitu sebesar 80,91 \% nilai tersebut menunjukkan bahwa media pembelajaran e-materi dengan model pembelajaran berbasis masalah termasuk dalam kriteria baik. Data yang diperoleh dari hasil uji coba ahli media yaitu data kualitatif dalam bentuk komentar dan saran terhadap media pembelajaran e-materi dengan model pembelajaran berbasis masalah. Hasil komentar dan saran yang diperoleh dari ahli media I dan ahli media II tersebut kemudian digunakan oleh peneliti untuk merevisi media pembelajaran yang akan dikembangkan.

\section{4) Uji Coba Kelompok Kecil}

Pada tahap ini data yang diperoleh adalah data kualitatif dalam bentuk komentar dan saran 
siswa terhadap desain media pembelajaran emateri yang dikembangkan. Uji coba ini dilaksanakan di SMAN 2 Palu dengan subjek sebanyak 8 orang siswa.

Data hasil analisis angket penilaian yang diperoleh dari uji coba kelompok kecil dapat dilihat pada tabel berikut:

TABEL IV HASIL ANALISIS ANGKET PENILAIAN UJI COBA KELOMPOK KECIL

\begin{tabular}{|c|c|c|c|c|}
\hline No & Item & $\begin{array}{l}\text { Rata-Rata } \\
\text { Hasil }(\%)\end{array}$ & Kualifikasi & Ket. \\
\hline 1 & Template & 87 & SB & $\mathrm{TR}$ \\
\hline 2 & Home & 81,67 & B & TR \\
\hline 3 & $\begin{array}{l}\text { Materi } \\
\text { Pembelajaran }\end{array}$ & 87,27 & SB & TR \\
\hline 4 & $\begin{array}{l}\text { Uji Kompetensi } \\
\text { Diri }\end{array}$ & 90,36 & SB & TR \\
\hline \multicolumn{2}{|r|}{ Rata-Rata } & 86,58 & SB & TR \\
\hline
\end{tabular}

Keterangan :

SB : Sangat Baik

B : Baik

TR : tidak Perlu Revisi

Tingkat pencapaian yang diperoleh dari hasil penilaian angket uji coba kelompok kecil yaitu sebesar $86,80 \%$ nilai tersebut menunjukkan bahwa media pembelajaran emateri dengan model pembelajaran berbasis masalah pada materi suhu dan kalor termasuk dalam kriteria sangat baik. Data yang diperoleh pada uji coba kelompok kecil adalah data kualitatif berupa komentar dan saran terhadap media pembelajaran yang dikembangkan. Hasil komentar dan saran tersebut kemudian digunakan untuk merevisi media pembelajaran yang akan dikembangkan dan siap diujicobakan pada kelompok yang lebih besar.

\section{5) Uji Coba Kelompok Besar}

Uji coba kelompok besar dilakukan di tiga sekolah yang berbeda yaitu SMA Negeri 2 Palu, SMA Negeri 3 Palu dan SMA Negeri 5 Palu.

Tahap uji coba lapangan ini dilakukan untuk memperoleh tanggapan siswa terhadap media pembelajaran yang dikembangkan. Data yang diperoleh dari hasil uji coba kelompok besar menunjukkan bahwa banyak siswa yang menginginkan adanya media pembelajaran emateri dalam proses belajar mengajar.

Pada tahap uji coba kelompok besar peneliti juga melakukan wawancara dengan perwakilan siswa. Dari hasil wawancara diperoleh beberapa informasi sebagai berikut:
1. Media pembelajaran e-materi merupakan sesuatu yang baru bagi siswa.

2. Video yang dimuat dalam e-materi dapat membantu siswa untuk lebih mudah memahami materi yang disediakan dalam emateri.

3. Uji kompetensi diri dapat membantu siswa dalam proses pembelajaran

4. Media pembelajaran e-materi yang dikembangkan menarik dan dapat digunakan sebagai media untuk belajar.

\section{6) Hasil Pengembangan}

Setelah melakukan beberapa tahap uji coba baik uji coba ahli maupun uji coba lapangan maka diperoleh hasil pengembangan media pembelajaran e-materi dengan model pembelajaran berbasis masalah pada materi suhu dan kalor yang baik dan siap untuk diproduksi dan digunakan di sekolah-sekolah yang memiliki fasilitas yang mendukung.

Media pembelajaran e-materi dengan model pembelajaran berbasis masalah pada materi suhu dan kalor yang dihasilkan merupakan media yang telah divalidasi dan direvisi sesuai dengan komentar dan saran yang diberikan oleh ahli materi, ahli media, dan siswa yang ikut serta dalam uji coba.

Selama pelaksanaan tahap uji coba, hampir semua bagian dalam media pembelajaran emateri ini mengalami revisi baik dari segi tampilan maupun isi. Revisi dilakukan berdasarkan komentar dan saran yang diperoleh dari hasil uji coba. Dari segi isi, komentar dan saran banyak didapat dari ahli materi I dan ahli materi II. Sedangkan dari segi tampilan, pada bagian home peserta uji coba baik ahli maupun siswa beranggapan bahwa tampilan home masih kurang menarik terutama pada bagian header. Berikut kutipan komentar dan saran dari ahli media dan siswa yang ikut serta dalam tahap uji coba.
Ahli media I : Pada Header, gambar background tidak perlu menggunakan repeat-x.

Ahli media II : Untuk Header posisi sebaiknya diletakkan di tengah agar lebih rapih dan menarik.

Siswa : Terlalu sederhana, warnanya redup dan jenis huruf yang digunakan tidak menarik. 


\section{Jurnal Pendidikan Fisika Tadulako (JPFT)}

Vol. 1 No. 2

Pada bagian uji coba kompetensi diri, peneliti juga melakukan revisi berdasarkan komentar dan saran dari ahli dan siswa. Berikut kutipan komentar dan saran yang diperoleh dari tahap uji coba.

Ahli media I : 1 . Content Uji Kompetensi Diri soal terkesan kaku \& minimnya penggunaan animasi

2. Logo (petunjuk/kunci jawaban) yang digunakan haruslah jelas. Pastikan users mengetahui logo tersebut adalah kunci jawaban, bukan petunjuk soal.

Ahli media II : Jawaban yang telah dipilih sebaiknya tidak bisa dirubah. (tombol/jawaban yang lain dinon-aktifkan)

Siswa : Secara umum tidak ada

Pada tahap uji coba lapangan, sebagian besar siswa beranggapan bahwa tampilan media pembelajaran e-materi yang dikembangkan sudah menarik, fitur materi dan uji coba kompetensi diri yang disediakan dalam media pembelajaran e-materi dapat membantu siswa dalam proses belajar sehingga secara umum siswa menginginkan agar media pembelajaran emateri ini juga dapat digunakan pada mata pelajaran lainnya.

Hasil pengembangan yang diperoleh yaitu media pembelajaran e-materi dengan model pembelajaran berbasis masalah pada materi suhu dan kalor. Adapun penjelasan tentang hasil pengembangan ini yaitu sebagai berikut:

\section{Home}

Ketika membuka halaman media
pembelajaran pembelajaran berbasis masalah pada materi suhu dan kalor, yang pertama kali muncul adalah tampilan menu home. Pada halaman depan (home) peneliti memberikan beberapa informasi tentang penyusunan media e-materi tersebut seperti tujuan pembuatan media e-materi ini, tahap penyusunan media e-materi dan materi yang dimuat dalam media e-materi. Informasi tersebut diberikan pada halaman depan agar pengguna dapat mengetahui tujuan dan materi yang dimuat dalam media e-materi tersebut. Tampilan halaman depan pada media pembelajaran e-materi ini dapat dilihat pada gambar berikut.

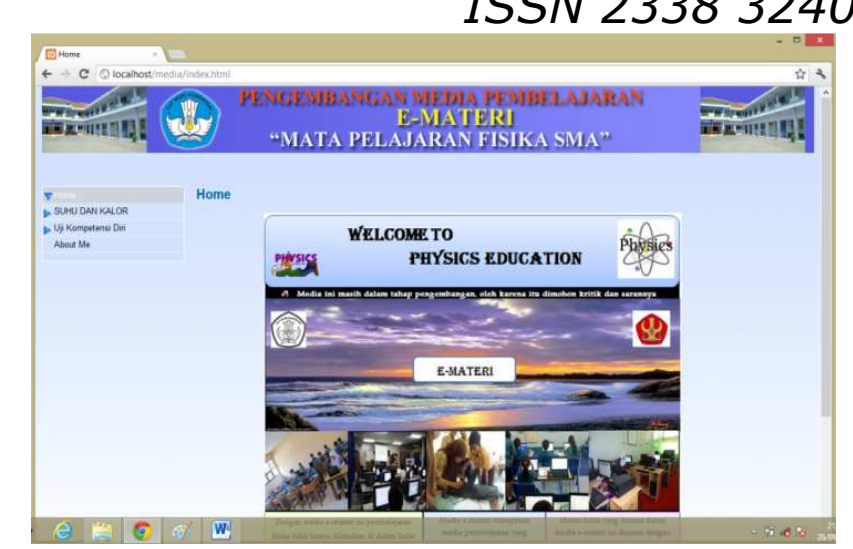

Gambar 2 Tampilan halaman depan media e-materi (Home)

\section{Materi}

Materi yang dimuat dalam media yang dikembangkan yaitu materi suhu dan kalor. Materi tersebut disusun dengan menggunakan tahapan-tahapan pada model pembelajaran berbasis masalah. Materi suhu dan kalor diambil sebagai materi yang akan dimuat dalam media pembelajaran e-materi karena materi tersebut merupakan salah satu materi fisika yang sifatnya abstrak. Selain itu, banyak dijumpai permasalahan-permasalahan yang berkaitan dengan materi suhu dan kalor dikehidupan sehari-hari. Sebelum materi tersebut dimuat dalam media pembelajaran e-materi, terlebih dahulu materi tersebut divalidasi oleh ahli materi I dan ahli materi II. Setelah dilakukan validasi kemudian dilakukan revisi sesuai dengan komentar dan saran dari ahli materi. Dalam menu materi pembelajaran suhu dan kalor tersedia beberapa sub menu yaitu Indikator dan Tujuan Pembelajaran, Lembar Kerja Kelompok (LKK), Rangkuman dan Glosarium.

\section{Uji Kompetensi Diri}

Menu uji kompetensi diri merupakan menu yang disediakan untuk melatih siswa dalam mengerjakan soal-soal. Adapun soal-soal yang disediakan dalam menu uji kompetensi diri ini yaitu soal pilihan ganda, soal benar-salah, soal jawaban singkat, kuis dan ujian tes. Untuk soal benar-salah, soal pilihan ganda dan soal jawaban singkat disediakan respon jawaban, sehingga siswa dapat mengetahui jawaban yang mereka pilih merupakan jawaban benar atau salah. Sedangkan untuk soal kuis dan ujian tes tidak disediakan respon jawaban secara langsung, namun dibagian belakang setelah siswa selesai mengerjakan soal kemuadian akan ditampilkan 
skor atau nilai yang diperoleh siswa dari hasil menjawab soal-soal tersebut.

Soal ujian tes yang disediakan pada menu uji kompetensi diri dibuat dengan menggunakan aplikasi macromedia flash 8 . Setelah soal tersebut selesai dibuat, kemudian disimpan dalam aplikasi EXE (e-learning XHTML editor).

Media pembelajaran e-materi dengan model pembelajaran berbasis masalah yang dikembangkan memiliki persamaan dan perbedaan dengan media pembelajaran yang pernah dikembangkan sebelumnya. Adapun persamaan dan perbedaannya yaitu sebagai berikut:

1) Persamaan

Media pembelajaran e-materi yang dikembangkan merupakan media pembelajaran yang memanfaatkan perkembangan teknologi yaitu penggunaan aplikasi komputer.

\section{2) Perbedaan}

Pengembangan media pembelajaran yang memanfaatkan aplikasi komputer sudah pernah dilakukan sebelumnya. namun, hasil pengembangan yang diperoleh berbeda-beda khususnya dari segi tampilan media yang dihasilkan dan aplikasi yang digunakan untuk menyusun media tersebut. Perbedaan hasil pengembangan media yang diperoleh dengan media pembelajaran yang dikembangkan sebelumnya yaitu sebagai berikut:

Media pembelajaran e-learning yang dikembangkan oleh [4] memiliki kelemahan khususnya pada menu kuis fisika. Soal pilihan ganda yang disediakan pada menu kuis fisika menggunakan aplikasi checkbox sehingga dapat memungkinkan pengguna memilih lebih dari 1 jawaban. Sedangkan soal pilihan ganda yang disediakan dalam media pembelajaran e-materi yang dikembangkan menggunakan dua aplikasi yaitu checkbox dan macromedia flash 8. Pada soal pilihan ganda yang dibuat dengan menggunakan aplikasi macromedia flash 8 pengguna/siswa tidak dapat memilih lebih dari satu jawaban. Jawaban yang dipilih oleh siswa tersebut dikunci dan siswa langsung dihadapkan dengan soal berikutnya. Setelah siswa selesai menjawab semua soal yang disediakan kemudian siswa dapat melihat skor/nilai yang diperoleh dari hasil menjawab soal.

Media pembelajaran yang dikembangkan oleh [1] merupakan media pembelajaran yang
ISSN 23383240

dikembangkan dengan menggunakan aplikasi macromedia flash. Hasil akhir dari media pembelajaran yang dikembangkan berupa video yang berisi materi pembelajaran dan animasianimasi. Sedangkan media pembelajaran emateri yang dikembangkan pada penelitian ini merupakan media pembelajaran yang dibuat dengan menggunakan aplikasi EXE (e-learning $X H T M L$ editor) sehingga dapat dibuka dengan menggunakan Mozilla firefox dan dapat digunakan secara luas dengan memanfaatkan Teknologi Informasi (TI) berupa intranet dan internet. Selain itu, aplikasi yang digunakan juga dapat memuat video yang dibuat dengan menggunakan macromedia flash.

\section{KESIMPULAN}

Kesimpulan yang dapat diambil dari penelitian ini adalah untuk mendapatkan produk akhir berupa media pembelajaran e-materi dengan model pembelajaran berbasis masalah pada materi suhu dan kalor yang memenuhi kriteria baik. Berdasarkan hasil analisa data yang diperoleh dari tahapan uji coba yaitu uji coba ahli isi materi, uji coba ahli media, uji coba kelompok kecil dan uji coba kelompok besar, maka dapat disimpulkan bahwa: media pembelajaran emateri dengan model pembelajaran berbasis masalah pada materi suhu dan kalor yang telah dikembangkan tergolong dalam kriteria baik sehingga layak untuk diproduksi dan digunakan di sekolah-sekolah dengan fasilitas mendukung.

\section{DAFTAR RUJUKAN}

[1] Rahman, R. dkk. (2008). Optimalisasi Macromedia Flash untuk Mendukung Pembelajaran Berbasis Komputer pada Program Studi Ilmu Komputer FPMIPA UPI. Jurnal pendidikan teknologi informasi dan komunikasi. 1, (2), 110.

[2] Mushon, A. (2010). Pengembangan Media Pembelajaran Berbasis Teknologi Informasi. Jurnal Pendidikan Akuntansi Indonesia. 8, (2), 1-10.

[3] Sadiman, Arief. (2010). Media Pendidikan, Pengertian, Pengembangannya, dan Pemanfaatannya cetakan ke 14 . Jakarta: Rajawali Press

[4] Syarif, Muh. (2012). Pengembangan Media Pembelajaran E-Learning Berbasis Web pada Materi Listrik Dinamis bagi Siswa SMA Kelas $X$ Semester II. Skripsi Universitas Tadulako Palu: Tidak diterbitkan. 